\title{
THE INFLUENCE OF SOCIAL MEDIA ON TEACHING AND RESEARCH IN NIGERIAN HIGHER INSTITUITIONS.
}

\author{
OLADIPUPO ABDULLAHI AKINOLA \\ DEPARTMENT OF GENERAL STUDIES THE FEDERAL POLYTECHNIC EDE, OSUN STATE, NIGERIA. \\ oladipupo7@gmail.com +2348033895148 \\ OYELEKAN CHARLOTTE OYEBIMPE \\ DEPARTMENT OF GENERAL STUDIES \\ THE FEDERAL POLYTECHNIC EDE, OSUN STATE, NIGERIA queenbimpe@yahoo.com +2348033843812 \\ ADEDEJI BABATUNDE ADEWOLE \\ DEPARTMENT OF GENERAL STUDIES
}

THE FEDERAL POLYTECHNIC EDE, OSUN STATE, NIGERIA tundeadedeji2005@yahoo.com+2348034747288

\begin{abstract}
Social media is a communication tool that was originally designed as a way for friends, family, or other groups of people to engage in discussions and interactions. They allow members to explore new opportunities and experiences. However, social media sites have now become an invaluable tool for teaching, learning and research at all levels of education most especially, in higher institutions. This paper therefore identifies different types of social media that are predominant in Nigeria and also examine different ways of using them to enhance teaching and research in Nigerian higher institutions.
\end{abstract}

\section{Keywords}

Influence, Social media, Teaching, Research, Communication

\section{Introduction}

Information and communication technology dominates the shebang of human activities. It has transformed the whole world into a global village (Adedeji 2011) it is the marriage between computer system and communication, which can be described as the use of computer-based technology and internet to make information and communication services available to a wide range of users (Ayannuga, 2009). Internet has become virile tool through which any society can be reckoned with in the comity of nations. This is because, internet which is a universal system of computer networks that are interconnected to serve millions or even billions of people around the world, connects people from every part of the globe. There is perhaps no better way of describing the information and technology connection in the 21st century besides social media which essentially convert media monologues into social dialogues through web-based technologies.

\section{What is Social Media?}

Social media is a term used to describe the type of media that is based on conversation and interaction between people online. They are designed to be disseminated through social interaction, using highly accessible and scalable publishing techniques (Alejandro, 2010). The great wave of web innovation, since Google in 1998 has been social media which is about networking and communicating through text, video, blongs, pictures, status updates on sites such as Facebook, Twitter, Myspace, WhatsApp, Youtube or Linkedin.

Social media has made significant impact on diverse facets of human endeavour, including politics, religion, commerce, medicine, law, education among others. Since it democratizes rather than monopolizes information and knowledge, social media transform users from content consumers only to both producers and consumers. It gives a voice to the voiceless and makes everybody an active participant. Because they are using social media to herald remarkable innovations and advances, the youth of these days have been tag as "Net Generation" "Digital Natives" and Digital Backpackers. They prefer receiving information quickly and process it rapidly. They prefer multi-tasking and non- linear access to information; have a low tolerance for lectures; prefer active rather than passive learning, and depend heavily on communication technologies to access information and to carry out social and professional interactions (Motajo and Oladipupo, 2014).

The impact of social media is predominantly being felt in all spheres of life. Religiously, social media are transforming believers and other adherents. More and more believers and a large number of congregations and religious institutions are using the social media and networking sites. They have become a means of sharing, caring, communing, witness advocacy and learning. For instance, Facebook and twitter are being used as vehicles for religious expression, exploration and engagement. Prominent Men of God like Pastor E.A Adeboye, Pastor Chris Oyahkilome, Shiek Gumi among others have Facebook account where they reach thousands of their followers.

The political impact of social media are being felt worldwide. Social media's real potential lies in supporting civil society and the public sphere. On January 17, 2001, during the impeachment trial of Philippine President Joseph Estrada, loyalists in the Philippine Congress voted to set aside key evidence against him. However, with the help of social media, thousands of Filipinos were able to protest until the president was removed, the event marked the first time that social media had helped force out a national leader. Social media was also used by President Barack Obama during the 2008 presidential election. He had over 170,000 followers. He used the Twitter buzz during the presidential debates as well as the election. In Nigeria also, prominent politicians like president Jonathan, Vice President Sambo, former president Obasanjo, Atiku Abubakar, Dr Okonjo Iweala, Governor Aregbesola and many others have both Facebook and Twitter accounts through which they reach their supporters and other citizens. 
In Marketing, it gives marketers opportunity to communicate with peers, customers and potential customers and consumers. It helps in personalizing the brand and helps to spread message in a relaxed and conversational way.

In addition, advertisement on social media is the cheapest of any form of advertisement. Some of these social media are discussed below

\section{Twitter}

Twitter, which was created in 2006 by Jack Dorsey, is an online social networking and microblogging service that enables users to send and read short 140- character text messages, called "tweets" Registered users can read and post tweets, but unregistered users can only read them. Users access twitter through the website interface. It is also described as "the SMS of the internet" it affords an individual opportunity to use SMS service to communicate with a small group. Twitter is really more of an information network than it is a social network because it is basically service for friends, family and coworkers to communicate and stay connected through the exchange of quick frequent messages. Twitter also allows you to follow other users you are interested in so that you will see their updates on your home page. Unlike e-mail, it provides this one-to-many interface for rapid content delivery and search.

In addition to using Twitter as a way to connect globally, it is also being used to share learning opportunities with others to outside of the classroom.

\section{Linkedln}

Linkedln is a social networking website for people in professional occupations. It was founded in 2002 . It is mainly used for professional networking. It is a business-oriented social networking site that enables users to connect with colleagues, and others with business relationships. Linkedln users invite people they know and trust to become "linked in" to them, and the business connections of invited users are in turn linked. However, in order to reach connections down the line, requests for introductions have to be made. A major feature of Linkedln is its groups, enabling anymore to start a group based on an association or industry topic. For instance, there are tens of thousand of academic and corporate groups that enable alumni and employees to stay in touch. Linkedin members request an invitation to the group and can receive postings by other members via e-mail. It serves as a platform that can assist both students and lecturers to gain greater understanding of communication and professionalism. It also helps in discovering new opportunity for collaboration, joint working, research, partnership and more. It is a form of electronic communication through which users create online communities to share information ideas, personal messages and other content.

\section{Myspace}

The site promotes social networking by giving access to meet new friends across the world. It also has music and videos that can be added to one's site for free. It offers e-mail, a forum, communities, video and weblog space.

It allows its users to create WebPages to interact with other users. Users are able to create blogs upload videos and photos, and design profiles to show case their interests and talents. The site was launched in 2003 in order to provide social forum for users to share pictures to specific group, comment to friends, and suggest friendship to other people. My space differs from other media by allowing individuals to create their content using HTML and also adding features based on customer demand. Moreover, Myspace used to be the most popular social networking sites until 2008 when Facebook was introduced ( Boyd \& Ellison, 2007).

\section{Facebook}

Facebook is a social networking service and websites. It is a social utility that connects people with friends, colleagues in the places of work among others, it allows users to create a personal profile with photos, lists of personal interests, contact information e.t.c. it can also add other users as friends and exchange messages, including automatic notifications. In addition, users may join common- interest user groups, organized by workplace, school, or other public or private institutions or establishments. Users of Facebook can communicate with friends and other users through private or public messages and a chat feature. Facebook allows users to choose their own privacy settings and choose who can see specific parts of their profile. The website is free to users. Users can control who sees other information they have shared, as well as who can find them in searches, through their privacy settings ( Cha, 2010) Facebook usage encompasses both the simple use of the platform and the extent of cognitive immersion into the site. It implies the presence of individual users on the social website, time spent on this platform, frequent visits, and the nature of the activities performed. People from different age ranges interact and exchange content; they share videos and pictures, discuss subjects, chat, publish advertisements for group events or play available applications. It also serves as a learning portal for the students because they use it to come together to discuss what they are working on. It usually contain definitions, photos, articles and discussion on their fields of study.

\section{2 go}

$2 \mathrm{go}$ messengers is a mobile messenger that allows the user to communicate for free with friends once the mobile device is downloaded and installed. It is a network where you can set up your profile, meet new people, talk to friend, share files and pictures. The $2 \mathrm{go}$ chat application is mostly popular in Africa because it easily allows the users to meet people within their locality, college or university. The 2 go chat software allows the user to add a friend thorough one's phonebook. In other words, 2 go chat messenger will allow one to chat with one's Facebook friends once the 2go account is connected to the Facebook account. 


\section{Relevance of Social Media in Nigeria.}

The usage of the social media is characterised by mixed feeling in Nigeria. Some schools of thought insist that there should be establishment of a framework for the regulation of the internet because in some cases, available information is not authentic and accessing it is complicated. Also people can post whatever they want; whether good or bad. Apart from lack of security and privacy, and confusion due to availability of many similar websites. Apart from these, it wastes users lives because many hours that could have been used to do something more important are wasted on social media. One might have unconsciously ruined ones life if one usually post offensive images and write unprintable things on his/her wall. This is because these days, inquisitive employers now visit applicant's social media updates to know more about him or her apart from the fact that users accounts can easily be hacked to commit crime.

However, social media has become a daily need for a lot people especially with the innovation that saw the emergency of social work websites which made more people to get involved in various online media where communication is increasingly channeled through by the newest social networks. For instance, Facebook allows the connection with friends, family and other relations virtually and this has made it a major application that connects people throughout the world and has therefore transformed relationships across the world. The impact of social media can be felt in the following aspects of human endeavours:

\section{Media Impact}

It has made it possible to get news as it unfolds. Social media is transforming users from content consumers only, to both content consumers and content producers. In the present global media climate, speed and immediacy are increasingly prioritized characteristics of news production. With social media like Facebook, Twitter and whatsApp, the idea of a single new item has been replaced by fast-changing content and news repertoires of constructing "Breaking News" (Kautsky \& Widholm, 2008). It has made it possible to quickly update, change and reshape news without having to wait for bureaucratic nature of traditional journalism which is mono linear, from writing, via editing to printing. The impact of the social media on the packing, distributing, delivery and reception of news is really being felt.

\section{Political Impact}

Social media has brought about what we call citizen journalism which also encourages the idea of citizen empowerment. It affords the people opportunity to write the comments on issues they feel are left out by the mainstream media. Rather than through professional journalists, the content is now being generated by the users and readers (social media users). It can be through texts, images audio files, podcasts or video. The rise in social media, has forced many newspapers, Radio stations and Television stations to set up websites with to interactive features where the public is allowed to comment and raise the issues without fear of being edited by the editors (Harkin; Anderson; Morgan \& Smith 2012) Some of these mainstream media is Nigeria allow and encourage public to participate and submit news items. For instance, Channels Television in Nigeria encourages their viewers to submit eye witness news by sending eye witness pictures to them via online (Banda, 2012) Unlike before when the coverage of the news by the mainstream journalist is "dependent on the mood... The politics of the journalist can affect the coverage. The politics of the senior editor on duty plays the main role on what make it to be aired on TV" (Harkin, et al, 2012).

\section{Social Impact}

Social media has affected the social life and activity of people in various ways. It has allowed the users to continuously stay in touch with friends, relatives and other acquaintances wherever they may be in the universe, as long as there is access to the internet. It also unites people with common interests through groups. In other words, its evolution has led to its use as the best medium for communication. Social media sites focus on building and reflecting social associations among people who share interests and activities. These social networks encourage people to share their personal experience with others through videos, music and other media.

\section{Economic Impact}

The uses of social media for business are largely based on the fact that they have large number of users. It serves as avenue to introduce and advertise both the new and old products. In other words, these social media site offer business owners excellent exposure for their business at a very cheap rate. Social media do not only create a massive targeted customer base that consists of people from all walks of life, it also allows the development of a business personality that connects with users and uses their opinions, reviews and life experiences to benefit the company's services and products.

\section{The Use of Social Media in Teaching and Research.}

Social media are used by teachers and students especially in the developed country as a tool of communication Professors and lecturers use forums and groups to extend classroom deliberations. Some of them use Twitter to communicate announcements and information to their students. It is a bi-directional process because students too are using these channels to share comment with their teachers. It also allows members to explore new opportunities and experiences and also affords the lecturers and students opportunity to express themselves, communicate and collect profiles that highlight their talent and experience. Apart from these, the following are some of the importance of social media to teaching and research.

1. They help both the lecturers and the students jointly engage in collaborative study, research or academic work.

2. They help in carrying out informal form of learning i.e. online degrees. 
3. They promote life long learning.

4. They enhance the various teaching and learning strategies required to meet the need of the teacher and the students.

5. Social media assist to foster research and development.

6. They help to widen access to education and the range of instructional options and opportunities for any-where, any-time, any-place and any-path learning (Adedeji, 2011).

7. They afford the teachers and researchers opportunities to enrich his research and professional life by reaching out to other fields and professions.

8. Social media allows classroom to hold after class discussion. In other words, the learning does not have to stop just because the class is over. Therefore, students can be encouraged to bring questions and discussion points from class on social media.

9. In other to reduce the work of the teachers, online community of students can be created. Social media can therefore be a tool for building camaraderie among the students and helping them to work together.

10. It serves as a source of feedback from students to lecturers. Immediate feedback can be got on course materials, lectures, texts and other topics via social media.

11. There are many research opportunities to be found on social media because so many archives, libraries have Facebook and Twitter accounts. One can therefore gather research data online from these sources.

12. Researcher's research result can be shared with other professionals in order to have immediate feedback.

13. Students and teachers can easily learn about the latest research. In other words, social media can help the teachers and students to keep up with new publication and discoveries in the larger academic community.

14. Social media motivate learners to make professional connections through social media. Learners can connect with experts in a variety of fields who can enrich their research and offer potential opportunities for internship and further learning.

\section{Objectives of the Study}

1. To examine the level of academic staff of Nigerian higher institutions on the use of social media.

2. To identify the most social media site used in Nigerian higher institutions.

3. To assess the level of social media usage among the academic staff of Nigerian higher institutions.

4. To determine the extent to which social media are used for teaching and researching.

\section{Theoretical Framework}

This study anchored on uses and Gratification theory. The Uses and Gratification theory which focuses on consumer or audience, instead of the actual message itself, assumes that members of the audience are not passive because they take active role in integrating media into their lives. The theory perceives the recipients as actually having influence on the effect process, since they selectively choose, attend to, perceive and retain the media messages on the basis of their needs, belief etc. the approach suggests that people use the media to fulfill specific gratifications (Blumler 1979).

The major assumption of this theory is that members of the audience are motivated in their selection of particular media and content types by determinable social and personal needs. Therefore, the focus has shifted from media function of production and transmission to the media consumption function. The uses and Gratification theory concerns the audience who derive some levels of satisfaction or reward (benefit) from using particular content of a particular media and that people seek out and use media to gain several gratifications (Folarin, 1998; Okenwa, 2002). Also, Defleur and Dennis (1994) explain further that members of the public will actively select and use specific forms of media content to fulfill specific forms of media content to fulfill their interest and motives.

\section{Methodology}

The population of the study consists of all the of academic staff of the Federal Polytechnic Ede. The institution has 375 academic staff including the Polytechnic Library Staff. Random sampling method was adopted to select 73 respondents, representing $20 \%$ across the four schools:

The Schools of Applied Science, Business Studies, Environmental Studies and Engineering. The total number of the respondents from those schools is shown in the table below:

\begin{tabular}{|l|l|l|}
\hline School/Faculty & Departments & $\begin{array}{l}\text { No of selected } \\
\text { respondents in } \\
\text { each } \\
\text { department }\end{array}$ \\
\hline Applied Science & Nutrition's & 2 \\
\hline
\end{tabular}




\begin{tabular}{|c|c|c|}
\hline & $\begin{array}{l}\text { Science Lab. Tech } \\
\text { Hotel \& Hospitality management } \\
\text { Statistic } \\
\text { Computer science } \\
\text { Tourism } \\
\text { Geological science }\end{array}$ & $\begin{array}{l}3 \\
2 \\
2 \\
2 \\
2 \\
1\end{array}$ \\
\hline Business Studies & $\begin{array}{l}\text { Accountancy } \\
\text { Banking and Finance } \\
\text { Business Administration and Management } \\
\text { Library and Information Studies } \\
\text { General Studies }\end{array}$ & $\begin{array}{l}3 \\
2 \\
3 \\
1 \\
5\end{array}$ \\
\hline Applied Science & $\begin{array}{l}\text { Nutrition \& Dietetics } \\
\text { Science Lab. Tech. } \\
\text { Hotel \& Hospitality Management } \\
\text { Statistics } \\
\text { Computer Science } \\
\text { Tourism } \\
\text { Geological Studies }\end{array}$ & $\begin{array}{l}1 \\
3 \\
2 \\
2 \\
3 \\
2 \\
1\end{array}$ \\
\hline Business Studies & $\begin{array}{l}\text { Accountancy } \\
\text { Banking and Finance } \\
\text { Business Administration and management } \\
\text { Marketing } \\
\text { Library \& Information Science }\end{array}$ & $\begin{array}{l}3 \\
2 \\
3 \\
2 \\
1\end{array}$ \\
\hline Engineering Studies & $\begin{array}{l}\text { Electrical / Electronic Engineering } \\
\text { Computer Engineering } \\
\text { Civil Engineering } \\
\text { Mechanical Engineering }\end{array}$ & $\begin{array}{l}2 \\
2 \\
2 \\
1\end{array}$ \\
\hline Environment Studies & $\begin{array}{l}\text { Architectural Technology } \\
\text { Building Technology } \\
\text { Estate Management } \\
\text { Quantitative Surveying } \\
\text { Surveying and Geo-informatics }\end{array}$ & $\begin{array}{l}2 \\
2 \\
2 \\
2 \\
2\end{array}$ \\
\hline Polytechnic Library & Library Unit & 3 \\
\hline TOTAL & & 73 \\
\hline
\end{tabular}

The research instrument used was questionnaire, and a 15- item copies of questionnaire was administered to each of the 73 respondents. The data collected were analyzed using the frequency method and simple percentage in order to make deductions and inferences.

\section{Summary of Findings}

From this study, the findings revealed that most of the Academic Staff in Federal Polytechnic Ede are aware of social media sites. It was also discovered that $93 \%$ of the staff has their own personal computer, be it desktop, or lap top. However it was discovered that $98.3 \%$ of the staff has social media accounts. It is therefore correct to say that the level of exposure of academic staff is considerably high. 


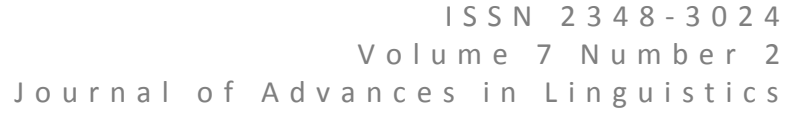

Most academic staff had been using the social media for about two to three years, with $59(80.8 \%)$ respondents. 12 $(16.4 \%)$ have been using it for about one year while others have not been using it at all.

The findings also indicated that 72 (98.6\%) respondents used Facebook as their social media site while 1(1.4\%) use Twitter only. However, some of those who use Facebook still used WhatsApp in addition to their Facebooks account.

The findings also showed that majority of academic staff do not use their social media sites for academic purposes. Only $7(9.5 \%)$ use their social media as a means of teaching researching while $66(90.4 \%)$ use it for communication and interactions with colleagues, friends and others.

\section{CONCLUSION}

The social media has become bedrock of communicating and exchanging of ideas among the people. It has positively affected the mutual interrelationship among the users and has successfully turned the entire world into a global village. However, the use of social media for teaching and research is still very low. This is because most of the users do not even realize that social media can be a data bank for teaching and research.

\section{Recommendations}

Since social media has become an essential means of exchanging ideas among the stakeholders in education domains, it is even obvious that majority, if not all the academics staff and students, cannot do without social media; be it 2go, Whatsapp, Facebook or Twitter, it is upon this that the following recommendations are made to ensure effective and purposeful use of social media in our higher institutions.

1. Government should ensure that the price of laptops and other computer accessories is drastically reduced

2. Social media learning should be included in the curriculum of post primary and post secondary institutions.

3. Effective E-learning centers should be set up in various higher institutions and also ensure that both academic staff and students have unlimited access to internet and social media.

4. Lecturers publications can be shared on social media like Facebook or Twitter in order to encourage the students to be using their time judiciously on social media

5. The school management should encourage both the lecturers and the students to cultivate the habit of using social media largely for academics purpose

6. Researchers should also be using various social media sites as data bank. For instance, questionnaires can be forwarded and administered to one's friends on Facebook and Twitter.

\section{REFERENCES}

1. Adedeji, B.A (2011) "The New Media and Literature: Treats and Threats".

2. Ayannuga, D.D (2009) "Information and Communication Technology. (ICT): A Veritable Tools for Manpower Development in Nigeria" COEASU journal of Contemporary Issues. Vol. 3 No1 pp 176-182

3. Banda, F. (2010) Citizen Journalism and Democracy in Africa. South Africa: Highway AFRICA.

4. Boyd, D.M and Ellison, N.B (2007) "Social Network Sites: Definition, History and Scholarship. Journal of Computer- Mediated Communication Vol. 13 no 1 Accessed 20-5-2013 http:// jcmc. Indianda. Edu/vol 13/issuel/ boyd. ellison. Html

5. Cha, J. (2010) "Factors Affecting the Frequency and Amount of Social Networking Site Use: Motivations, Perceptions, and Privacy Concerns". First Monday Vol. 15 no12 Accessed 20-5-2013 http:// www.uic.edu/ htbin/ cgiwrap/ bin/ojs/index. Php/fm/article/ view Article/ 2889/

6. Defleur, M.L and Dennis, E.E (1994) Understanding Mass Communication: A Liberal Arts Perspectives. Boston: Houghton.

7. Folarin, B. (2001) Theories of Mass Communication, An Introductory Text. 2nd Edition, Abeokuta: Link Publications.

8. Harkin, J.; Anderson, k; Morgan, Land Smith, B. (2012) Deciphering User-Generated Content in Transitional Societies. Pennsylvania: Annenberg.

a. I-JDSEET vol.1 no1 pp 165-170

9. Kautsky R and Wildholm A (2008) "Online Methodology: Analysis News Flow of Online Journalism”. Westminster Papers in Communication and Culture Vol. 5 No 2 pp 81-98.

10. Madrigal, A (2011) Twitter's fifth Beatle Tells His Side of Story. The Atlantic Accessed 26/05/2014

11. Motajo, A.I and Oladipupo A.A (2014) How to Pingintellingently and Tweetellectually to Enhance Learning for Optimum Employability in Nigeria. A paper presented at the 13th Annual National Conference of School of Business Studies, Federal Polytechnic Ede.

12. Okenwa, S. (2002) The Mass Media; Theories and Realities. Enugu: Busmark.

13. Schmitt, T.L, Sims Giddens, S.S Booth R.G (2013) "Social Media Use in Nursing Education" Online Journal of Issues in Nursing,Vol.17 No3 Accessed 19-06-2014 